$\xi=-1$

\title{
Building the image of city through organizational support and community commitment
}

\author{
Juanim Juanim ${ }^{1 *}$, Ina Ratnamiasih ${ }^{1}$ \\ ${ }^{1}$ Department of Management, Universitas Pasundan, Bandung, Indonesia \\ *Corresponding author E-mail: juanim@unpas.ac.id
}

\begin{abstract}
This research is in progress to meet the overall research grant on the city's image. Images are a very important thing for a city. With a good image of the city, will bring many tourists, businessmen, as well as investors. this will certainly encourage the increase in income expected by the community, along with the image of the city is increasing. Bandung is one of Indonesia's unique city. The city is constantly trying to improve its brand image. to improve the brand image of Bandung city influenced by several variables, the most influential is community commitment and government support. The results of the research with the spread of questionnaires on 100 respondents, proved that community commitment and organizational support greatly influenced the increase of brand image of the city of Bandung. Several recommendations have been given to support the improvement of the brand image of the city of Bandung, especially recommendations on how to improve organizational support and community commitment.
\end{abstract}

Keywords: City Image, Organizational Support, Community Commitment

\section{Introduction}

The last decade of the city's image and reputation concept has been intensively observed by researchers, but is considered a key factor in the success of a region. The ability of a city to get the necessary resources is affected by its image and reputation [1] Cities with these characteristics have many opportunities to sell the products and services they offer, even the lifestyles and values of the community become a high selling point for people from outside the city $[2,3]$. The big cities in Indonesia have long tried doing branding of the city development. Many of the desired goals of the branding include attracting many domestic tourists and even foreign tourists. However, there is no city that has a very strong branding in Indonesia from the view of visitors. especially from international tourists. Bandung City is one of the creative cities in the Asia Pacific region, has been selected as a creative city pilot project in East Asia, as stated at the international meeting of creative economy-based cities in Yokohama, followed by eleven countries in 2007. Brand city of Bandung as Emerging Creative City, starting in 2008.

Tourists make a return visit due to satisfactory service and in accordance with needs [4]. Based on previous research. We can show that the identity of the city has not been supported by any parties involved. An initial survey of the prominent advantages of the city of Bandung is culinary, fashion and recreational Tourism. This indicates that the people of Bandung have creativity, especially in terms of design categories [5, 6].

Although the city of Bandung has many advantages, the response to the image of Bandung city majority shows a bad image. Some people look Bandung as the city of congestion and garbage. Government support for city image is not only done through the socialization of regulations and policies but also the provision of infrastructure. However, the image of Bandung is still not strong.
The image of the city is built through a complex and lengthy process $[7,8]$.

Therefore, developing a city brand should be coherent and clear with government support and community commitment. should be as much as possible to avoid major changes in government policy in the process of developing the image of the city from time to time, so the development process will be consistent with the expected city branding [7]. Through this research, to obtain the extent of the impact of organizational support or government policy can have an impact on community commitment and how big the role of organizational support in influencing community commitment and its implications in improving the image of Bandung.

\section{The research theory}

Place branding is believed to be a way of making places famous. Implementation of theories and concepts marketing tools to complex entities such as cities is not something obvious [7]. The utility for public organizations to implement marketing tools as development tools [9]. Brand image is the cumulative image of a city in the mind of a person. Because of the diversity in city image drivers and the way that individuals filter and integrate perceptions in their own minds, there is no single, monolithic brand image for a city $[10,11]$.

However, the benefits of a city brand provide reasonable living expenses, adequate housing, public security, transportation systems, salary, culture and recreation, etc [1].

Unfortunately, the marketing of a region is important to explain how far the region in which the city wants to be known by outsiders (reputation or city brand) [12]. The characteristics of a region are largely determined by the role of stakeholders involved in the process in this case the regional leaders and the community, while how management conducts socialization is often not easy to understand [13]. 
To enhance the brand role of a place, the government must consider many elements in building a strong competitive advantage, some of which are good infrastructure, basic services available, and interesting attractions $[13,14]$.

To improve its physical image, the city or region can act on the perception of its inhabitants. all types of media can also be used to disseminate, promote and remind people of their image to people who are not residents of the region or city, as well as trigger awareness of their perceptions [7]. A good area must have a supportive environment that consists of a clear vision, access to wellinformed information, strong support, providing resources, a very clear role, and also a broad range of controls is a participatory climate that encourages and build the motivation of all subordinates to grow together and develop [15].

A. favorable organization support tends to increase the exchange between cities and communities. The perception of organizational support is the extent to which employees perceive an organization's appreciation of their contribution and how much the organization has a level of awareness of their welfare aspect [16] as well as to employee satisfaction [17].

Cities are a very complex area because they are composed of very complex social people and groups. The image of a city must be shaped by so many of the commitments of the people and institutions they develop that they create, they evolve over time and which is the impact of their beliefs and the behavior of their government leaders.

The public commitment to the city brand is very important, it is to give people a reason and strengthening so important the image of the city so that everyone will have motivation and passion, the public will be able to give an assessment of whether its compatibility capability with the big scheme of trademarks offered and promised to external parties and how much impact they have on achieving the goals desired by a city. The public can also reward the cities or regions that are able to improve the desired and desired brand performance, and will ensure that all kinds of business factors need to be concentrated or focused [18].

Brand assimilation is a series of programs designed to ensure that the entire community can understand, recognize or remember and include them both in and out of the city [18]. Successful brand awareness when a commitment to the city is manifestly demonstrated by society. People understand the meaning of the brand and show it by translating it into real behavior. Society speaks, acts and thinks in the direction that the brand has developed [9]. The community's commitment to the brand will create and create a strong relationship between the citizens of the city and this visitor will have an excellent impact on the city.

Organizational commitment is the extent to which a person is involved in an organization following the process according to the goals, culture and values established by the organization [19]. Organizational commitment is also a strong acceptance of the goals and values of the organization and has a high trust to run it, have and give maximum effort, and the desire to stay and stay in the organization [20,21]. Based on the above definition, this can be used as a reference to explain its interconnection with a region or city, that the social community within the region that is committed to the city are people who are aware and have confidence and trust in the leadership of the city government, the vision and purpose of the city, and the desire to become an inseparable part of the city, in accordance with the purpose of the established city. Organizational commitment can be grouped into three, namely: a). ongoing commitment, b). normative commitment, c). affective commitment [19]. Affective commitment is the most appropriate part to be used to discuss community commitment. This illustrates how the priest has an emotional involvement with the organization and self-identification $[19,21]$.

\section{Research methods}

The main data collection techniques used in research using questionnaires. Respondents in this study is Bandung society. The sampling technique used is purposive sampling method to select the respondent. Out of 120 distributed questionnaires, only 100 were returned for analysis. Data analysis method used is Structural Equation Model (SEM), it is used to test the existence of relationship pattern between variables that become the object of research. The goal is to know the magnitude of direct and indirect influence both between independent variables, dependent and intervening.

\section{Results and discussion}

The result of analysis with structural equation model can be seen in the Figure 1. Based on the confirmatory factor analysis results show Goodness of Fit Index such as Chi-square 143.721, Probability $=0,022$ RMSEA $=0,053, \mathrm{CMIN} / \mathrm{DF}=1,286, \mathrm{TLI}=0,903$, CFI $=0914$. Based on testing the Goodness of Fit Index this model indicates suitability.

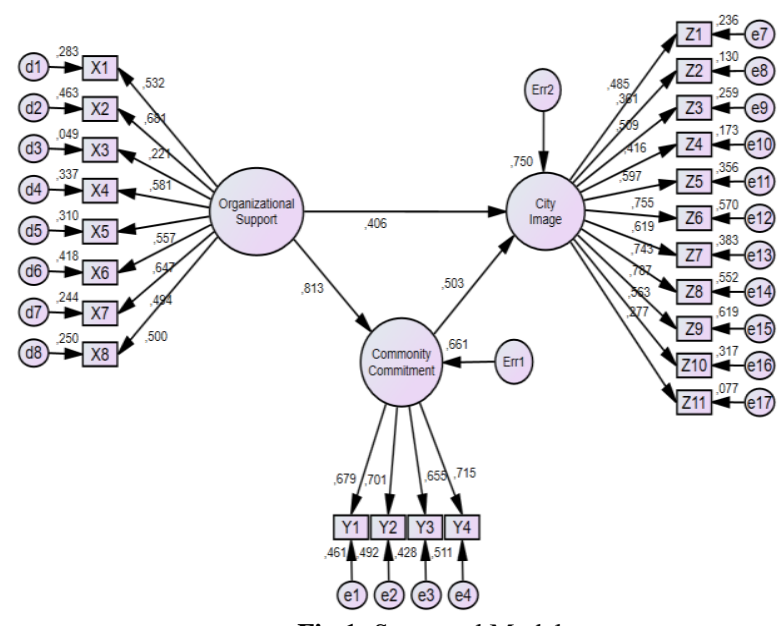

Fig.1: Structural Model

Based on the results, all hypotheses have a significant impact. Organizational support gives a high and significant influence to the community commitment of 0.813 , as well as community commitment has a significant effect on city image of 0.503 and organizational support for the image of the city also has an effect of 0.406

Results from testing the direct and indirect effects between variables. shows that with large organizational support will implicate indirectly to the city image mediated by Community Commitment. The effect of organizational support on urban image through Community Commitment is 0.409 . The total Organizational Support to the image of the city has an effect of 0.815 .

\section{Conclusions and practical implication}

The results of this study indicate that the image of the city is determined by the support of the organization in which the value of community commitment has been shown to have a high influence as a mediating variable. This means that if the support of the organization is increasingly greater, the commitment of the community will also be greater so that it will have implications for improving the image of the city [22]. This illustrates that organizational support indirectly affect the city image, organizational support will have a higher impact and significantly to the city image if community commitment is also high [23]. Support from public organizations has an important role to encourage and elevate community motivation to have strong trust and commitment, so that people will feel compelled to involve themselves in an effort to encourage the creation of a good city image [18].

Assessment of organizational support, good or bad, is determined by the extent to which facilities are provided by the government, perceived comfort, standing buildings, and other facilities simultaneously and simultaneously forming the image of the city. 
Therefore, the organization's support for infrastructure and city park as a social and spatial city in Bandung should be in good organization and certainly need to be supported by society with high commitment. The commitment of the community will be created if the bond between community members and certain communities builds up, therefore the city of Bandung must have a program to increase the bond among the community members so that they have the confidence that their involvement as members of the community will build the image of the city, big profits that are not easily obtained and felt elsewhere [24]. In turn, will increase community loyalty and commitment as members of the community, of course the impact will form a unique city brand.

This study was conducted in one city with limited respondents. For that reason, subsequent research will be done by developing it. Therefore, the results of this study should be interpreted with caution. This is a study that proposes an explanatory model, we are considering developing further studies into several cities with different cultural characteristics and taking into account the number of representative populations and samples.

\section{References}

[1] Popescu AI (2012), Management \& Marketing. 7, 493512.

[2] Morgan N, Pritchard A, PrideR \& Morgan N (2011), Butterworth-Heinemann, Oxford.

[3] Hankinson G (2001), J. of Brand Management. 9, 127142.

[4] Dragolea LL \& Cotîrlea DA (2012), Annales Universitatis Apulensis Series Oeconomica, 14, 680687.

[5] Juanim J, Rahmawati, NL (2015), Trikonomika 14(1), 6675.

[6] Juanim J, Ratnamiasih I (2017), International Review of Management and Marketing, 7(5), 916.

[7] Balencourt A \& Zafra AC (2012), Umeå School of Business Spring, Master thesis, one year, $15 \mathrm{hp}$.

[8] Anholt S (2004), Burlington: Elsevier ButterworthHeinemann. 2639.

[9] Kotler P. \& Levy (1969), J. of Marketing. 33, 1015

[10] Cromwell T (2013), East West Communications.

[11] Anholt S (2010), Editorial: Place Branding and Public Democracy. 6,110 .

[12] Hospers GJ (2004), Intereconomics. 39, 271279.

[13] Petrea R, Petrea D, Olău PE \& Filimon L (2014), Transylvanian Review of Administrative Sciences. Special Issue, 124140.

[14] Kotler P, Asplund C, Rein I \& Haider D (1999), Pearson Education Limited, London.

[15] Braun E \& Zenker S (2010), 50th European Regional Science Association Congress, Sweden.

[16] Fu FQ, Bolander W \& Jones E (2009), J. of Marketing Theory and Practice. 17, 335350.

[17] Yoon J (2010), A thesis submitted for the degree of Doctor of Philosophy, Brunel University.

[18] Prophet. www.prophet.com, (2002).

[19] Allen NJ \& Meyer JP (1990), J. of Occupational Psychology. $63,118$.

[20] Chen LY (2004), J. of American Academy of Business, Cambridge. 5,432438 .

[21] Kulkalyuenyong P (2012), School of Public Administration National Institute of Development Administration. 1148.

[22] Braun E \& Kavaratzis M (2010), 50th European Regional Science Association Congress, Jönköping, Sweden.

[23] Yoon JK (2009), J. of Visual Communication Design. 31, 120129.

[24] Hospers GJ (2010), European Planning Studies. 18, 20732081. 